\title{
Aktivitas Perlindungan Tabir Surya Secara In Vitro Dari Ekstrak Etanol Kulit Buah, Kulit Biji dan Biji Pinang Yaki (Areca vestiaria Giseke)
}

\author{
Irmawati Anggriania*, Max R. J. Runtuwenea, Vanda S. Kamua \\ Jurusan Kimia, FMIPA, Unsrat, Manado
}

KATA KUNCI

Pinang Yaki

SPF

Tabir Surya

\begin{abstract}
A B S T R A K
Penelitian ini bertujuan untuk menguji aktivitas perlindungan tabir surya dari ekstrak etanol kulit buah, kulit biji dan biji pinang yaki secara in vitro. Tahap pendahuluan penelitian ini yaitu menguji nilai SPF (Sun Protection Factor) yang dilakukan secara invitro dengan menggunakan metode spektrofotometri UV-Vis. Serbuk kulit buah, kulit biji dan biji dimeserasi dengan pelarut etanol kemudian dipekatkan dengan rotary evaporator sehingga menghasilkan ekstrak pekat. Ekstrak etanol kulit buah, kulit biji dan biji pinang yaki memiliki nilai SPF yang berbeda yaitu 12,05 , 3,45 , dan 1,00. Dari nilai SPF ketiga sampel tersebut, kulit buah yang memiliki nilai SPF tertinggi dan termasuk dalam kategori Proteksi Maksimum sehingga kulit buah pinang yaki dapat dilakukan uji lanjut tentang aktivitas perlindungan tabir surya secara in vivo.
\end{abstract}

K E Y W O R D S

Pinang Yaki

SPF

Sunscreen

\begin{abstract}
A B S T R A C T
The purpose of this study were to test the sunscreen protection activity of ethanol extract of the skin of Pinang Yaki fruit, shell skin and seed by using in vitro method. The preliminary stage of this research was to test the value of SPF (Sun Protection Factor) by invitro using UV-Vis spectrophotometry method. Skin of Pinang Yaki Fruit, shell skin and seed were maceration with ethanol then concentrated with a rotary evaporator to produce a concentrated extract. Skin of Pinang fruit, shell skin and seed have different SPF values of 12.05, 3.45, and 1.00. From the SPF values of the three samples, the skin of the fruit has the highest SPF value and is included in the Maximum Protection category so that the skin of Pinang Yaki fruit could be tested futher for sunscreen protection activity by in vivo method.
\end{abstract}

TERSEDIA ONLINE

01 Agustus 2017

\section{Pendahuluan}

Matahari merupakan sumber cahaya dan energi setiap mahkluk hidup. Di balik manfaatnya, matahari memiliki radiasi sinar UV yang dapat membahayakan kulit. Radiasi sinar ultraviolet (UV) dapat memberikan dampak merugikan bila terpapar berlebihan terutama paparan dari sinar UV-A dan sinar UV-B (Baumann et al., 2009). Tabir surya berfungsi menyerap, memantulkan atau menyebarkan sinar matahari yang berada pada daerah emisi radiasi UV sebelum diserap oleh tubuh. Penggunaan zat-zat yang bersifat antioksidan dapat mencegah berbagai penyakit yang ditimbulkan oleh radiasi sinar UV, beberapa golongan senyawa aktif antioksidan seperti fenolik, flavonoid, tanin, antraquinon, sinamat telah dilaporkan memiliki kemampuan sebagai perlindungan terhadap sinar UV. Penggunaan antioksidan alami merupakan cara yang paling aman untuk menghindari adanya efek samping yang berbahaya dari antioksidan sintetik (Depkes, 2000). Salah satu bahan alam yang memiliki kandungan antioksidan yang baik adalah pinang yaki. Pinang yaki merupakan salah satu tanaman hias yang tumbuh di Sulawesi Utara yang dimanfaatkan sebagai obat untuk penyakit diabetes serta diare 
dan juga dipakai sebagai obat kontrasepsi (Simbala, 2006). Menurut Mamonto et al. (2014), buah pinang yaki mengandung senyawa-senyawa metabolit sekunder seperti alkaloid, flavonoid, triterpenoid, steroid, dan tanin yang memiliki sifat antioksidan sehingga memungkinkan untuk memberikan perlindungan terhadap sinar UV. Penelitian ini bertujuan untuk menentukan nilai SPF (Sun Protection Factor) dari kulit buah, kuli biji dan biji pinang yaki yang dapat dilakukan uji lanjut mengenai aktivitas perlindungan tabir surya secara in vivo.

\section{Material dan Metode Alat dan Bahan \\ Alat yang digunakan dalam penelitian ini adalah peralatan gelas (Iwaki Pyrex), vortex, oven (Memmert), rotary evaporator, timbangan analitik (Adam PW254), lampu Exoterra (15 Watt), spektrofotometer UV-Vis (Shimadzu UV-1800) \\ Bahan yang digunakan dalam penelitian ini adalah kulit buah, kulit biji dan biji pinang yaki yang diambil dari gunung Mahawu (Tomohon, Sulawesi Utara), tabir surya, aquades, tikus putih galur wistar, etanol 96\%, asam stearat, cera alba, vaselin putih, TEA (Trietanolamin), propilen glikol, reagen Folin Ciocalteau.}

\section{Prosedur Penelitian}

\section{Preparasi Sampel}

Buah pinang yaki dibersihkan dari pengotor lalu dipisahkan antara kulit biji, biji dan kulit buah. Kulit buah pinang yaki dikering anginkan selama 7 hari kemudian diblender. Setelah halus, kulit buah pinang yaki diayak menggunakan ayakan ukuran 65 mesh, sehingga menghasilkan serbuk kulit buah pinang yaki.

\section{Uji Kadar Air (Wilkinson dan Moore, 1982)}

Wadah kosong sebagai media sampel ditimbang dan dicatat beratnya sebagai $A$. Kemudian sampel yang telah dipreparasi ditimbang sebanyak 2 gram (B), dan dipanaskan dalam oven dengan temperatur pemanasan $105^{\circ} \mathrm{C}$ selama 3 jam. Setelah tiga jam, sampel dimasukkan kedalam desikator selama 30 menit. Kemudian, berat akhir sampel ditambah wadah ditimbang dan dicatat beratnya sebagai C. Perhitungan kadar air menggunakan rumus berikut :

Keterangan :

$$
\text { Kadar air }=\frac{(A+B)-C}{B} \times 100 \%
$$

$A=$ Berat wadah

$\mathrm{B}=$ Berat sampel sebelum dipanaskan

$\mathrm{C}=$ Berat sampel + wadah setelah dipanaskan

Ekstraksi ( Kadji et al., 2013)

Ekstraksi sampel dilakukan sesuai dengan prosedur dari Kadji (2013). Sebanyak 500 g serbuk diekstraksi dengan cara maserasi selama 3×24 jam menggunakan pelarut etanol sebanyak $4500 \mathrm{ml}$, selanjutnya disaring hingga diperoleh filtrat. Filtrat yang diperoleh kemudian dievaporasi menggunakan rotary evaporator pada suhu $50^{\circ} \mathrm{C}$, kemudian dipekatkan ke dalam oven $40{ }^{\circ} \mathrm{C}$ selama 6 jam hingga diperoleh ekstrak pekat.

Uji aktivitas perlindungan Sinar UV (Wang et al., 2008 yang dimodifikasi)

\section{Secara In Vitro}

Penentuan efektivitas perlindungan terhadap sinar UV dilakukan secara in vitro dengan alat spektrofotometer UV-Vis. Ekstrak buah pinang yaki dibuat dengan konsentrasi $10.000 \mu \mathrm{g} / \mathrm{mL}$, caranya diambil sebanyak 0,1 gram masing-masing krim ekstrak kulit buah pinang yaki dilarutkan dalam etanol 96\% sebanyak $10 \mathrm{ml}$ dicampur hingga homogen. Larutan yang telah diperoleh diukur dengan spektrofotometer UV-Vis pada panjang gelombang 290-400 nm dengan menggunakan etanol sebagai blanko. Nilai serapan dicatat setiap interval $5 \mathrm{~nm}$ dari panjang gelombang 290-320 nm. Hasil absorbansi dicatat kemudian dihitung nilai SPF nya dengan menggunakan persamaan :

$$
\mathrm{SPF}=\mathrm{CF}_{\mathrm{x}} \sum_{290}^{\mathrm{a} 20} \mathrm{EE}(\lambda) \mathrm{x}(\lambda) \mathrm{x} a b s(\lambda)
$$

Dimana :

$$
\begin{aligned}
& \mathrm{CF}=\text { Faktor Koreksi } \\
& \mathrm{EE}=\text { Spektrum efek eritema } \\
& \mathrm{I}=\text { Spektrum intensitas matahari } \\
& \mathrm{Abs}=\text { Absorbansi sampel }
\end{aligned}
$$

\section{Hasil dan Pembahasan \\ Uji Kadar Air}

Pengujian kadar air dilakukan bertujuan untuk menentukan kadar air dari sampel kulit buah Pinang Yaki. Kadar air yang diharapkan memiliki presentase dibawah 10 \% karena apabila sampel memiliki nilai kadar air yang besar, maka ditakutkan sampel akan menghasilkan mikroorganisme yang dapat menyebabkan perubahan konformasi senyawa kimia yang terkandung pada sampel. Hasil pengujian kadar air ditunjukkan pada Tabel 1.

Tabel 1. Kadar Air Buah Pinang Yaki

\begin{tabular}{cc}
\hline Pengujian Ke- & Kadar Air (\%) \\
\hline I & 7,82 \\
II & 7,19 \\
III & 7,81 \\
\hline
\end{tabular}

\section{Ekstraksi Kulit Buah Pinang Yaki}

Serbuk kering kulit buah pinang yaki sebanyak $500 \mathrm{~g}$ diekstraksi dengan metode maserasi menggunakan pelarut etanol sebanyak $4500 \mathrm{ml}$ secara berulang-ulang yaitu $3 \times 24$ jam. Pengulangan dilakukan dengan tujuan untuk mengoptimalkan proses ekstraksi maserasi dalam mengikat senyawa yang terkandung pada sampel. Maserasi merupakan cara ekstraksi yang paling sederhana dengan cara merendam serbuk simplisia menggunakan pelarut yang sesuai dan tanpa pemanasan dan terlindung dari cahaya. Hasil dari 
proses ekstraksi maserasi berupa cairan berwarna jingga. Maserat yang diperoleh kemudian dipekatkan dengan rotary evaporator. Dari serbuk sebanyak $500 \mathrm{~g}$ diperoleh berat ekstrak sebanyak $17,678 \mathrm{~g}$ sehingga rendemennya adalah 3,5356 $\%$ (rincian perhitungannya dapat dilihat pada lampiran 3).

\section{Uji aktivitas perlindungan Sinar UV}

\section{Secara In Vitro}

Tabel 2. Hasil uji perlindungan tabir surya secara in vitro

\begin{tabular}{cc}
\hline Sampel & Nilai SPF \\
\hline Kulit Buah & 12,05 \\
Kulit Biji & 3,45 \\
Biji & 1,00 \\
\hline
\end{tabular}

Pada analisis secara in vitro, yang dilakukan dengan menggunakan metode spektrofotometri UVVis dengan cara menghitung nilai absorbansi sampel yang dibaca pada panjang gelombang 290$400 \mathrm{~nm}$ kemudian setiap interval $5 \mathrm{~nm}$ (290-320 $\mathrm{nm}$ ) dicatat absorbansinya dan dihitung menunjukkan bahwa ekstrak kulit buah pinang yaki memiliki nilai SPF 12,05, kulit biji 3,45 dan biji 1,00. Berdasarkan hasil tersebut, kulit buah yang memiliki nilai tertinggi dan termasuk dalam kategori Proteksi Maksimum sehingga memungkinkan untuk dilakukan uji lanjut yaitu aktivitas perlindungan tabir surya secara in vivo.

\section{Kesimpulan}

Bedasarkan hasil penelitian yang dilakukan dapat disimpulkan bahwa ektrak kulit buah pinang yaki memiliki nilai SPF dalam kategori proteksi maksimum sehingga bias dilakukan uji lanjut tentang aktivitas perlindungan tabir surya secara in vivo.

Daftar Pustaka

Ayu, C. 2008. Pengaruh Bentuk Sediaan Krim, Gel, dan Salep Terhadap Penetrasi Aminofilin Sebagai Antiselulit Secara in Vitro menggunakan Sel Difusi Franz. [Skripsi]. FMIPA UI, Jakarta.

Baumann, L. B., Saghari, S. dan Weisberg, E. 2009. Cosmetic Dermatology, Principles and Practice. The Mc-Graw-Hill Medical, New York.

Budiman, M.H., 2008. Uji Stabilitas Fisik Krim Antioksidan Ekstrak Serbuk Tomat [Skripsi]. FMIPA UI, Jakarta.

Conde, E.F., Cadahia, M.C., Garcia-Vallejo, B.F.D. Simon and Adrados, J.R.G. 1997. Low Molecular Weight Polyphenol in Cork of Quercus Suber. J. Agric. Food Chem. 45: 2695-2700

Dutra, E. A., Daniella., A.C., Erika, C., Maria, R.M.K. dan Suryani, I.R.M. 2004. Determination of Sun Protection Factor (SPF) of Sunscreen by UV Spectrophotometry. Brazilian Journal of Pharmaceutical Sciences. 40: 381-385

Mamonto, I. S., Runtuwene, M. R. J. dan Wehantouw, F. 2014. Aktivitas Antioksidan
Ekstrak Kulit Biji Buah Pinang Yaki (Areca Vestiaria Giseke). Jurnal IImiah FarmasiUNSRAT. 3: 263-272.

Simbala, H. 2006. Keanekaragaman Floristik dan Pemanfaatannya Sebagai Tumbuhan Obat Oleh Masyarakat di Kawasan Konservasi di Taman Nasional Bogani Nani Wartabone Kab.Bolaang Mongondow. [Disertasi]. IPB, Bogor.

Wang, S.Q., Stanfield, M.S. dan Osterwalder, U. 2008. In Vitro Assessment of UV A Protection by Populer Sunscreen Available in the United States. J Am Dermatol. 59: 934-942. 